\title{
Epiphytic bryophytes in urban forests of Wrocław (SW Poland)
}

\author{
Ewa Fudali* \& Ludwik Żołnierz
}

Wroclaw University of Life and Environmental Sciences, Department of Botany and Plant Ecology, pl. Grunwaldzki 24a, 50-363 Wrocław, Poland

* corresponding author (e-mail: ewa.fudali@gmail.com; ORCID: http://orcid.org/0000-0001-7923-8748)

\begin{abstract}
Data documenting the occurrence of epiphytic bryophytes in the urban forests of the Wroclaw city were collected and reported for the first time. Research was carried out in 2015-2016, in forest areas situated within the city administrative boundaries, to find whether some epiphytic species reported from the Wroclaw environs in the 19th century and presently considered to be primeval forest relicts occur in urban forests. The survey was carried out using the established network of 50 study plots randomly scattered within the urban forested areas. In total 42 species (4 liverworts and 38 mosses) were recorded on 467 trees; three of them are primeval forest relicts. In this paper, the host-tree preferences, distribution in the individual forests, relative frequency, abundance and exposure to compass directions of the studied taxa are analysed. Of the species described, only 17 are obligatory epiphytes, while 22 of them are character forest species. However, $82 \%$ of the latter were noted on a small number of tree trunks. Two moss taxa, Hypnum cupressiforme and Platygyrium repens, were most frequently found (on 76 and $50 \%$ of the trees, respectively). Among the species recorded in the studied area, there are five that have been showing some expansive tendencies in Europe in recent decades. The potential ability of these species to spread in urban areas is discussed in relation to their general ecological requirements.
\end{abstract}

Key words: urban bryoflora, host tree preferences, expansive bryophytes, primeval forest relic species

\section{Introduction}

Contemporary world becomes more and more urbanized, and urbanization brings the most important threats to biodiversity at regional and, even, continental scales. Two processes generated by urbanization, i.e., (1) the loss of many native plant species, both locally rare and widespread, and (2) the expansion of a relatively small group of species adapted to strongly modified habitats at the city core lead to urban biotic homogenization and decline of regional biotic uniqueness (Kowarik 1990; Jackowiak 1998; Mc Kinney 2006). To retain the biological distinctiveness of urbanized areas the preservation of native species in urban habitats is postulated in last decades (Mc Kinney 2006; Dearborn \& Kark 2009; Dyderski et al. 2017). But establishing long-term biodiversity management plans has to be based on understanding historical patterns of change, which is not possible without current studies within cities and their comparison with historical data (Alvey 2006).
A key habitat for preservation of many epiphytic bryophyte species in urban environment is urban forest, because these plants are very sensitive to changes in their habitats regarding air moisture and precipitation chemistry. Therefore they avoid human-modified environments (Seward 1979; Winner 1988; Fudali 1996; Vanderpoorten 1997). Recently, that group of bryophytes has experienced dynamic changes in their distribution in Europe, in respect of both natural and urban ecosystems (e.g., Greven 1992; Bates et al. 1997; Stapper \& Kricke 2004; Fudali 2012, 2018; Stebel et al. 2012; Stebel \& Fojcik 2016; Sérgio et al. 2016).

In the spatial structure of Wroclaw, urban forests, which are remnants of a former large forest, occupy circa $7.6 \%$ of the city area (Lewicki 2014). Within these forests, a comprehensive bryological research documented in the literature have not been conducted so far (Fudali 1998). Only for three epiphytic bryophyte species, Platygyrium repens, Anomodon longifolius and Ortotrichum fastigiatum, detailed localities, presently situated within the Wroclaw urban forests, were reported 
in the past (Milde 1869). In the bryophyte collection of the Herbarium of Wroclaw University (WR), there are some specimens of two other epiphytic mosses, Homalia trichomanoides and Anomodon attenuatus, collected in the urban forests in the year 1955 (Górski et al. 2017). Thus, our knowledge of the epiphytic bryophyte species diversity in the urban forests of Wroclaw is very poor, which contrasts strongly with the data about 36 bryophytic epiphytes occurring in the Wroclaw municipal parks (Fudali 2012). In the Bryologia Silesiaca (Milde 1869), there were listed 19 epiphytic bryophyte species found in the Wroclaw region (germ. kreis Breslau) of which 16 were forest species. Wroclaw (germ. Breslau) was pointed as a general locality (without strictly defined geographical location) for three of them: Orthotrichum Lyellii, O. stramineum and $O$. tenellum, while the Wroclaw surroundings (germ. um Breslau) - for four: Homalia trichomanoides, Orthodicranum montanum, Amblystegium juratzkanum and Orthotrichum pumilum.

Our goal was to describe the general features of epiphytic bryophyte flora of the Wroclaw urban forests. We addressed the following questions: $(i)$ what is the species spectrum and richness of epiphytic bryophyte flora in the Wroclaw urban forests? (ii) what is the share of obligatory epiphytic species as compared to those able to occur on other substrata as well? (iii) what are the preferences of epiphytic bryophyte species for the host-tree species? (iv) do the rare species recorded in the historical references still occur in the forests of Wroclaw?

\section{Material and methods}

\subsection{Study area and location of the forests}

Wroclaw, situated in the south-western part of the country in the Odra River valley, is one of the biggest towns in Poland. It occupies an area of $293 \mathrm{~km}^{2}$ and is inhabited by about 640,000 people. The city is located on a flat area formed by the Odra River and its five tributaries, which flow at the altitudes of 95-125 $\mathrm{m}$ a.s.1. and occupy about $3 \%$ of the city area. In these river valleys, the remnants of natural vegetation, forests and wet meadows have been preserved. Rural areas with sparsely arranged buildings and garden plots dominate in the spatial structure of Wroclaw ( $45 \%$ of the city area); they are partly fallowed and recently systematically built-up with residential estates. A compactly built-up centrum covers about $30 \%$ of the city area (Lewicki 2014). Forests are predominantly situated in western, northern and north-eastern suburbs and occupy circa $7.6 \%$ of the city area (Fig. 1). Six of them are isolated wooded islands (Las Leśnicki, Las Pilczycki, Las Osobowicki, Las Strachociński, Las Wojnowski, and forest on Opatowicka Isle) and another four represent fragments of bigger forest complexes adjacent to the city. Three of the studied forests are Natura 2000 areas (Las Ratyński, Las Strachociński, and Las Pilczycki).

\subsection{Forest vegetation}

Potentially, two types of deciduous forests occur within the Wroclaw boundaries: mesophilous oak-

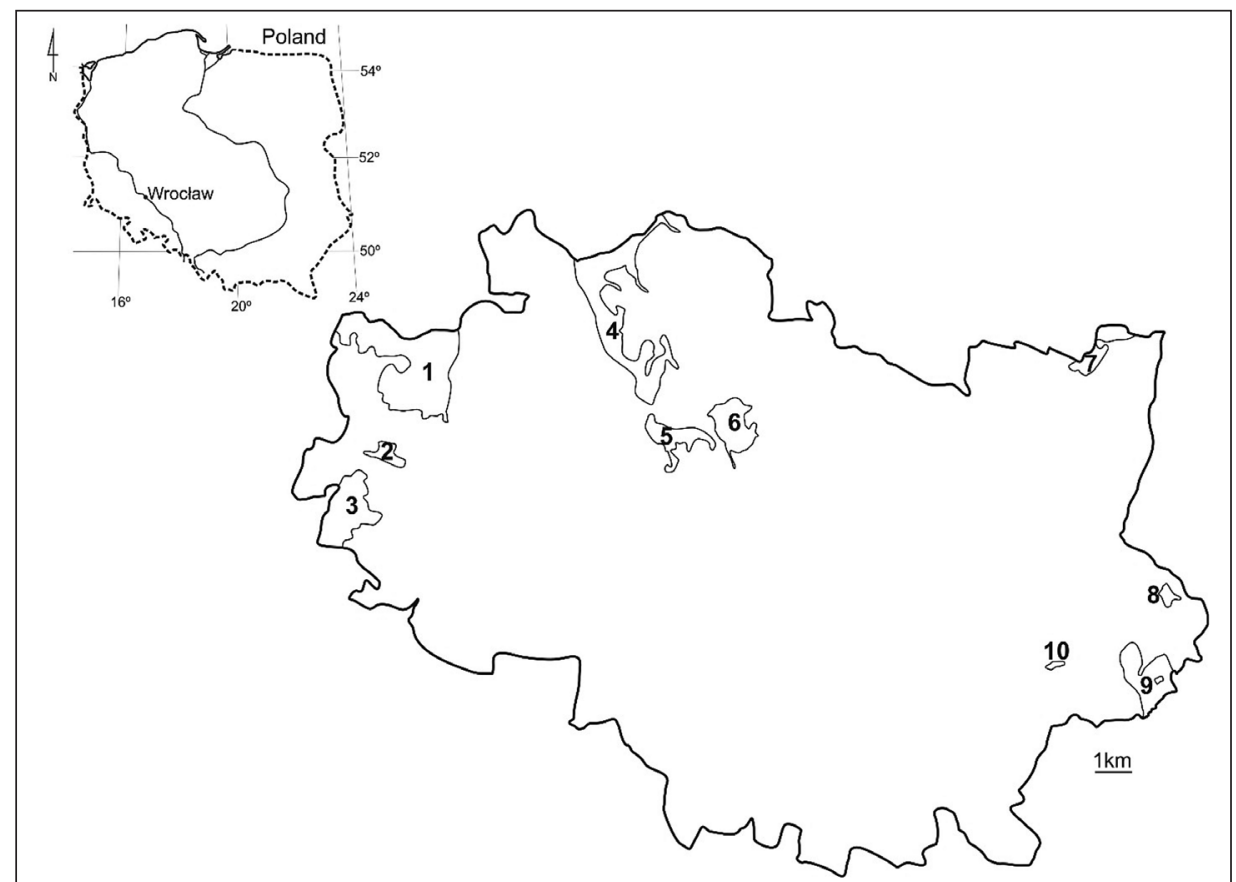

Fig. 1. The urban forests studied in the area of Wroclaw

Explanations: 1 - Mokrzański Forest, 2 - Leśnicki Forest, 3 - Ratyński Forest, 4 - Rędziński Forest, 5 - Pilczycki Forest, 6 - Osobowicki Forest, 7 - Zakrzowski Forest, 8 - Wojnowski Forest, 9 - Strachociński Forest, 10 - forest on Opatowicka Isle 


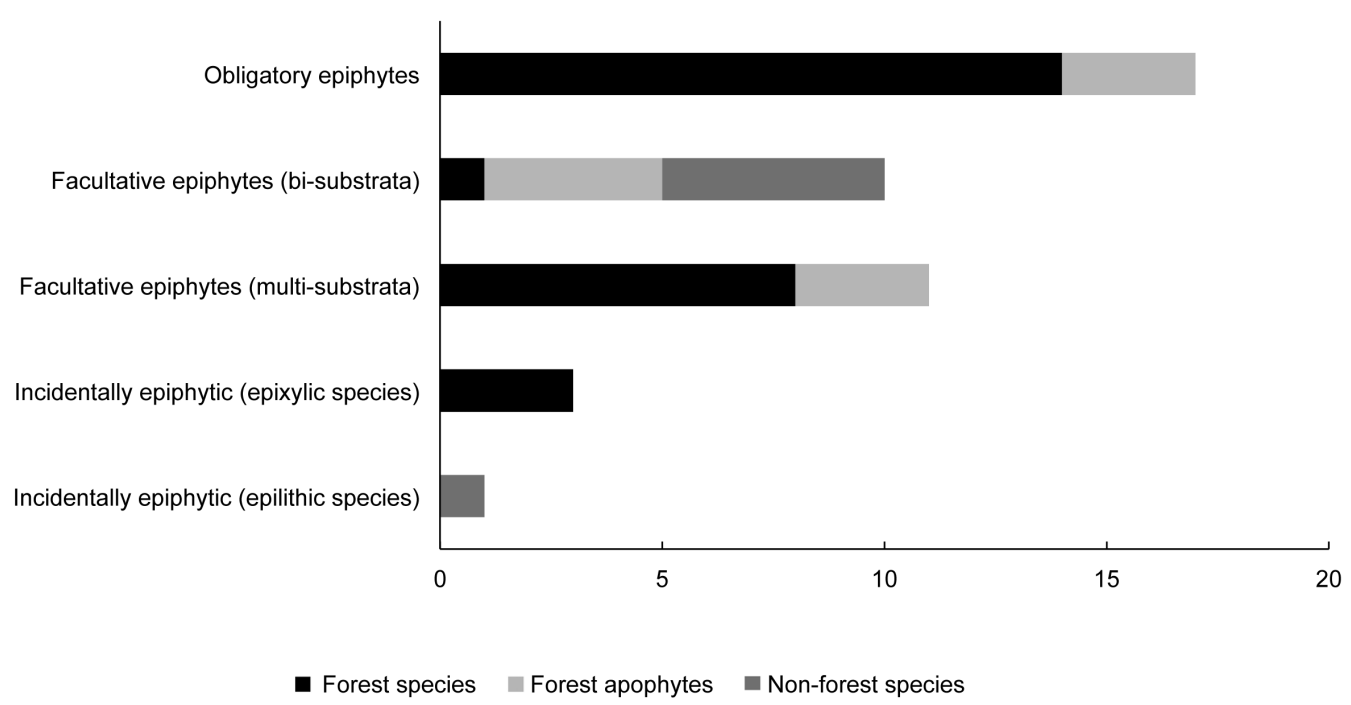

Fig. 2. Spectrum of bryophyte species in the Wrocław forests representing various affinities to forest ecosystems and tree trunks as substratum

hornbeam forest representing the Galio sylvaticiCarpinetum betuli (R.Tx. 1937) Oberd. 1957 association, a lowland form, both typical and humid varieties, and wet elm-ash forest representing the FraxinoUlmetum (Knapp 1942 em. J. Mat. 1976) association (Matuszkiewicz et al. 1995). Actually, in most sites, the latter occurred in the degraded form due to drying of its natural habitats. The average age of forest stands is 75 years and they comprise $57 \%$ of Quercus robur L. and Q. petraea (Matt.) Liebl. (Cichocki 2006). In these forests, some sylviculture operations, such as clearing and cutting, have been carried out.

\subsection{Climate}

Rainfall is highly variable and annual total rainfall ranges between 318 and $892 \mathrm{~mm}$. Series of wet years with an annual rainfall higher than $600 \mathrm{~mm}$ are quite frequent. The average annual precipitation in the $20^{\text {th }}$ century was $583 \mathrm{~mm}$. The average annual temperature is $9^{\circ} \mathrm{C}$ and the annual temperature amplitude is $19.2^{\circ} \mathrm{C}$. Winters are short (65 days) and mild, with frequent periods of warming in February of up to $10-15^{\circ} \mathrm{C}$. The most frequent winds are from a westerly direction (27.6\% of days in a year; the highest speed of $4.4 \mathrm{~m} / \mathrm{s}$ is during winter and $3.4 \mathrm{~m} / \mathrm{s}$ in summer) and from the south $(23.1 \%)$, winds from the north and north-east are rare (7\%) (Dubicki et al. 2002).

\subsection{Sampling design}

Research was based on the network of 50 of 100x100 m research plots randomly situated within the urban forests. From here on, they will be called "squares" to distinguish them from the plots from which bryosociological relevés were sampled. Vegetation records were made in 2015-2016; their methodology followed the principles of Richter et al. (2009), with some modifications. In every square (found in the field using a GPS device), all trees with a girth of more than $30 \mathrm{~cm}$ (minimal limitation taken from Mežaka et al. 2008) were studied at the height range of 0.8-1.2 m above ground level to establish the presence of epiphytic bryophytes. Bases of trees were excluded from the investigation, as they differ in ecological conditions from trunks and are often overgrown with competitive epigeic bryophytes (Barkmann 1958). On the trees with epiphytes, plots were established on an area of $30 \times 40 \mathrm{~cm}$ and a list of the species and their coverage (expressed in percentage) in the plot (=bryosociological relevé) was estimated. Total coverage summarized for all relevés expressed in $\mathrm{dm}^{2}$ was used in the species comparison. Expositions of the relevés were noted. Species that could not readily be identified in the field were sampled and subsequently determined in the laboratory. Altogether, 506 relevés were sampled. For each relevé, the host tree species identity was also documented. In total, 467 individual trees were studied.

Classes of relative frequency were determined as follows: very frequent species, recorded on $100-80 \%$ of trees with bryophytes; frequent, $79-60 \%$; quite frequent, $59.9-40 \%$; rare, $39.9-20 \%$; very rare, less than $20 \%$, including a subclass of extremely rare that occurred on no more than $5 \%$ of the trees colonized.

The nomenclature of mosses follows Ochyra et al. (2003), with the exception of Rosulabryum moravicum (Podp.) Ochyra \& Stebel, and for liverworts follows Szweykowski (2006). Names of tree species were taken from Mirek et al. (2002).

Bryophytes living on tree trunks differ in their ability to colonize also other substrata. Therefore, two categories of epiphytes have been distinguished in bryophyte ecology: obligatory (found only on tree trunks) and facultative (also recorded on other substrata 
Table 1. Species occurring on tree trunks in the individual urban forests studied, arranged according to their relations to corticolous habitats, with the general data of their frequency, abundance and number of tree species colonized

\begin{tabular}{lcccccccccccccccc}
\hline Symbol of the forests studied & 1 & 2 & 3 & 4 & 5 & 6 & 7 & 8 & 9 & 10 & & & \\
Number of squares & 12 & 2 & 5 & 8 & 7 & 5 & 2 & 4 & 3 & 2 & A & B C & D \\
Trees with epiphytes & 76 & 10 & 53 & 108 & 78 & 5 & 43 & 42 & 35 & 17 & & \\
\hline
\end{tabular}

Name of species

Anomodon attenuatus (Hedw.) Hueb.

Anomodon viticulosus (Hedw.) Hook \& Taylor

Dicranoweisia cirrata (Hedw.) Lindb.

Dicranum scoparium Hedw.

Homalia trichomanoides (Hedw.) Schimp.

Hypnum pallescens (Hedw.) P. Beauv.

Isothecium alopecuroides (Lam. ex Dubois) Isov.

Leskea polycarpa Hedw.

Metzgeria furcata (L.) Dumort.

Orthodicranum montanum (Hedw.) Loeske

Orthodicranum tauricum (Sapjegin) Smirnova

Orthotrichum affine Schrad. ex Brid.

Orthotrichum pumilum Sw.

Plagiothecium laetum Schimp.

Platygyrium repens (Brid.) Schimp.

Ptilidium pulcherrimum (Veber) Voit.

Radula complanata (L.) Dumort.

1) bi-substrata

Amblystegium serpens (Hedw.) Schimp.

Ceratodon purpureus (Hedw.) Brid.

Hypnum cupressiforme Hedw.

Lophocolea heterophylla (Schrad.) Dumort.

Orthotrichum diaphanum Schrad.

Sciuro-hypnum reflexum (Starke) Ignatov \& Huttunen

Pylaisia polyantha (Hedw.) Schimp.

Rosulabryum moravicum (Podp.) Ochyra \& Stebel

Sciuro-hypnum populeum (Hedw.) Ignatov \& Huttunen

Syntrichia virescens(De Not.) Ochyra

2) multi-substrata

Brachytheciastrum velutinum (Hedw.) Ignatov \& Huttunen Sciuro-hypnum oedipodium(Mitt.) Ignatov \& Huttunen

Brachythecium rutabulum(Hedw.) Schimp.

Brachythecium salebrosum(Hoffm. ex Weber \& Mohr)

Schimp.

Kindbergia praelonga (Hedw.) Ochyra

Mnium hornum Hedw.

Plagiomnium cuspidatum (Hedw.) T.J. Kop.

Plagiothecium curvifolium Schliep. ex Limpr.

Plagiothecium nemorale (Mitt.) A. Jaeger

Plagiothecium succulentum (Wilson) Lindb.

Pohlia nutans (Hedw.) Lindb.

3) incidentally epiphytic

- epixylic

Aulacomnium androgynum (Hedw.) Schwägr.

Herzogiella seligeri (Brid.) Z. Iwats.

Tetraphis pellucida Hedw.

- epilithic

Dryptodon pulvinatus (Hedw.) Brid.

$\sum$ of the bryophyte species
Number of trees colonized

Obligatory epiphytes

\begin{tabular}{|c|c|c|c|c|c|c|c|c|c|c|c|c|}
\hline . & 13 & 1 & 6 & & . & 2 & . & . & 5 & 6 & 22 & 32.8 \\
\hline & . & 1 & & & & . & . & - & 1 & 1 & 1 & 4.8 \\
\hline 32 & 2 & 26 & 14 & 4 & 5 & 8 & 17 & 3 & 15 & 27 & 117 & 77.9 \\
\hline \multirow[t]{2}{*}{14} & 3 & 3 & 2 & . & 1 & & 5 & $\cdot$ & 7 & 8 & 30 & 2.4 \\
\hline & 23 & 6 & 8 &. & . & 4 & . & 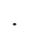 & 5 & 8 & 41 & 24.9 \\
\hline \multirow[t]{2}{*}{8} & 4 & 21 & . & . & . & . & . & 1 & 9 & 9 & 38 & 41 \\
\hline & 2 & & & . & . & . & . & & 1 & 1 & 2 & 0.8 \\
\hline \multirow[t]{2}{*}{3} & . & 2 & 1 & . & . & . & . & 1 & 3 & 4 & 7 & 2 \\
\hline & . & & 1 & . & . & . & . & . & 1 & 1 & 1 & 0.1 \\
\hline 12 & 3 & 9 & . & . & . & 3 & . & 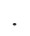 & 8 & 12 & 27 & 32.7 \\
\hline 6 & 1 & 4 & 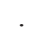 & & &. & 1 & . & 5 & 7 & 12 & 3.1 \\
\hline 2 & 3 & 3 & 6 & 1 & 11 & 1 & 2 & 4 & 13 & 13 & 33 & 2.4 \\
\hline 1 & 4 & 8 & 3 & 2 & 6 & 2 & 4 & 5 & 12 & 13 & 36 & 2.9 \\
\hline 1 & 1 & 1 & 1 & & & & . & 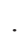 & 2 & 3 & 4 & 3.8 \\
\hline 15 & 25 & 54 & 39 & 1 & 26 & 31 & 30 & 6 & 20 & 28 & 232 & 61.2 \\
\hline 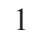 & . & 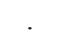 & & . & & . & . & . & 1 & 1 & 1 & 0.1 \\
\hline & 10 & 5 & 3 & & 3 &. &. & 1 & 7 & 8 & 22 & 7.1 \\
\hline
\end{tabular}

\begin{tabular}{|c|c|c|c|c|c|c|c|c|c|c|c|c|c|}
\hline 1 & 1 & 17 & 28 & 33 & . & 8 & 9 & $\cdot$ & 7 & 17 & 19 & 104 & 113.2 \\
\hline 1 & & & 1 & & & & . & & & 2 & 2 & 2 & 0.6 \\
\hline 55 & 6 & 32 & 80 & 58 & 2 & 37 & 26 & 43 & 15 & 24 & 37 & 354 & 541 \\
\hline 14 & 2 & 3 & 7 & 1 & . & 1 & 2 & 2 & & 8 & 16 & 32 & 4 \\
\hline . & . & 2 & 2 & 5 & . & 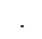 & 2 & . & 3 & 6 & 4 & 14 & \\
\hline$\cdot$ & . & . & . & . & . & 1 & . & . & $\cdot$ & 1 & 1 & 1 & \\
\hline . & . & 1 &. & 1 & 1 & 1 & . & . & 1 & 1 & 3 & 5 & \\
\hline . & . & 2 & 19 & 13 & . & 2 & 3 & . & 3 & 9 & 12 & 41 & 16. \\
\hline . & . & 4 & 3 & 1 & . & . & 1 & . & . & 2 & 4 & 9 & \\
\hline$\cdot$ & . & $\cdot$ & 1 &. & . & . & . &. & . & 1 & 1 & 1 & 0.0 \\
\hline . & . & . & 7 & 4 & . & . & 2 & . & 1 & 7 & 7 & 14 & 13. \\
\hline . & . & 1 & 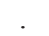 & . & . & . & . & . & . & 1 & 1 & 1 & \\
\hline . & . & 4 & 7 & 8 & . & . & 2 & . & 3 & 9 & 8 & 24 & \\
\hline$\cdot$ & . & 9 & 8 & 6 & . & 5 & 1 & . & . & 7 & 9 & 29 & 37 \\
\hline . & . & 1 &. & 1 & . & . &. &. & . & 2 & 2 & 2 & \\
\hline 1 & . & . & . & . & . & . & . &. & . & 1 & 1 & 1 & \\
\hline 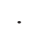 & . & . & 1 &. & . & $\cdot$ & . &. & . & 1 & 1 & 1 & \\
\hline . & . & . & 1 &. & . & . & 1 & . & . & 2 & 2 & 2 & \\
\hline . & . & . & 1 &. & . & . &. &. & . & 1 & 1 & 1 & \\
\hline & . & . & . & 1 & . & 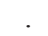 & . &. & . & 1 & 1 & 1 & \\
\hline 1 & . & 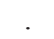 &. & 1 & . & . & . & . & . & 2 & 2 & 2 & \\
\hline
\end{tabular}

0.6

541

4.8

0.5

4.7

16.6

2.6

0.03

13.6

0.5

14.1

37.2

0.4

2.5

3.6

1.9

0.2

0.1

Explanations: A - number of host tree species colonized, B - number of squares in which the species occurred, C - number of trees colonized, D - total cover of the species in the relevés $\left[\mathrm{dm}^{2}\right]$ 
as rocks, wood or soil). The species classification as an obligatory or facultative epiphyte always refers to regional conditions (Barkmann 1958). In our study, the species affiliation to obligatory or facultative epiphytes was based on bryological data published so far from Wroclaw and its vicinity (Berdowski 1974; Fudali 2001, 2011, 2012). Among facultative epiphytes three groups were defined: $(i)$ bi-substrata - noted in Wroclaw with high frequency both on tree trunks and walls; (ii) multi-substrata - colonizing three or more substrata and often growing at tree bases, but rarely noted in higher positions on trunks, and (iii) incidentally epiphytic showing clear specialization to other substrate (e.g., walls, decayed wood) and sporadically recorded on trunks.

The species affiliation to forest ecosystems was estimated on the basis of phytosociological characterization of bryophytes by Dierssen (2001) and aforementioned bryological data from Wroclaw. Three categories were distinguished: (i) forest species that rarely occur outside forests, (ii) forest apophytes, i.e., species that occur frequently both within and outside forests, and (iii) non-forest species, occurring mostly outside forests.

\section{Results}

3.1. Species and ecological diversity of corticolous bryophytes

Bryophytes occurred in 43 squares studied (86\%). Within these squares, 42 bryophyte species were recorded comprising 4 liverworts: Radula complanata, Ptilidium pulcherrimum, Metzgeria furcata and Lophocolea heterophylla, and 38 mosses (Table 1).

Most of the species recorded (26) are forest bryophytes; ten of the other species represent a group of forest apophytes (the liverwort Lophocolea heterophylla and mosses-Amblystegium serpens, Brachytheciastrum velutinum, Brachythecium rutabulum, Dicranoweisia cirrata, Hypnum cupressiforme, Orthotrichum pumilum, Plagiothecium laetum, Plagiomnium cuspidatum, and Rosulabryum moravicum, ), and six belong to the group of non-forest moss species (Ceratodon purpureus, Dryptodon pulvinatus, Orthotrichum diaphanum, Pylaisia polyantha, Sciuro-hypnum reflexum, Syntrichia virescens).

17 species were classified as obligatory epiphytes, and they were mainly forest species (Table 1, Fig. 2). To the group of bi-substrata facultative epiphytes belong 10 species, and these species were mostly forest apophytes or non-forest species. The group of multi-substrata facultative epiphytes contains 11 species, which are mostly forest species, and the group of incidentally epiphytic species is formed by four taxa: three of them are forest specialists (epixylic species) and one - nonforest (epilithic moss).

\subsection{Relative frequency and distribution in forests}

Four species were the most frequently found: Hypnum cupressiforme classified as 'frequent', Platygyrium repens - as 'quite frequent', and Dicranoweissia cirrata and Amblystegium serpens - as 'rare'. Other species were recorded on no more than 50 trunks, which places

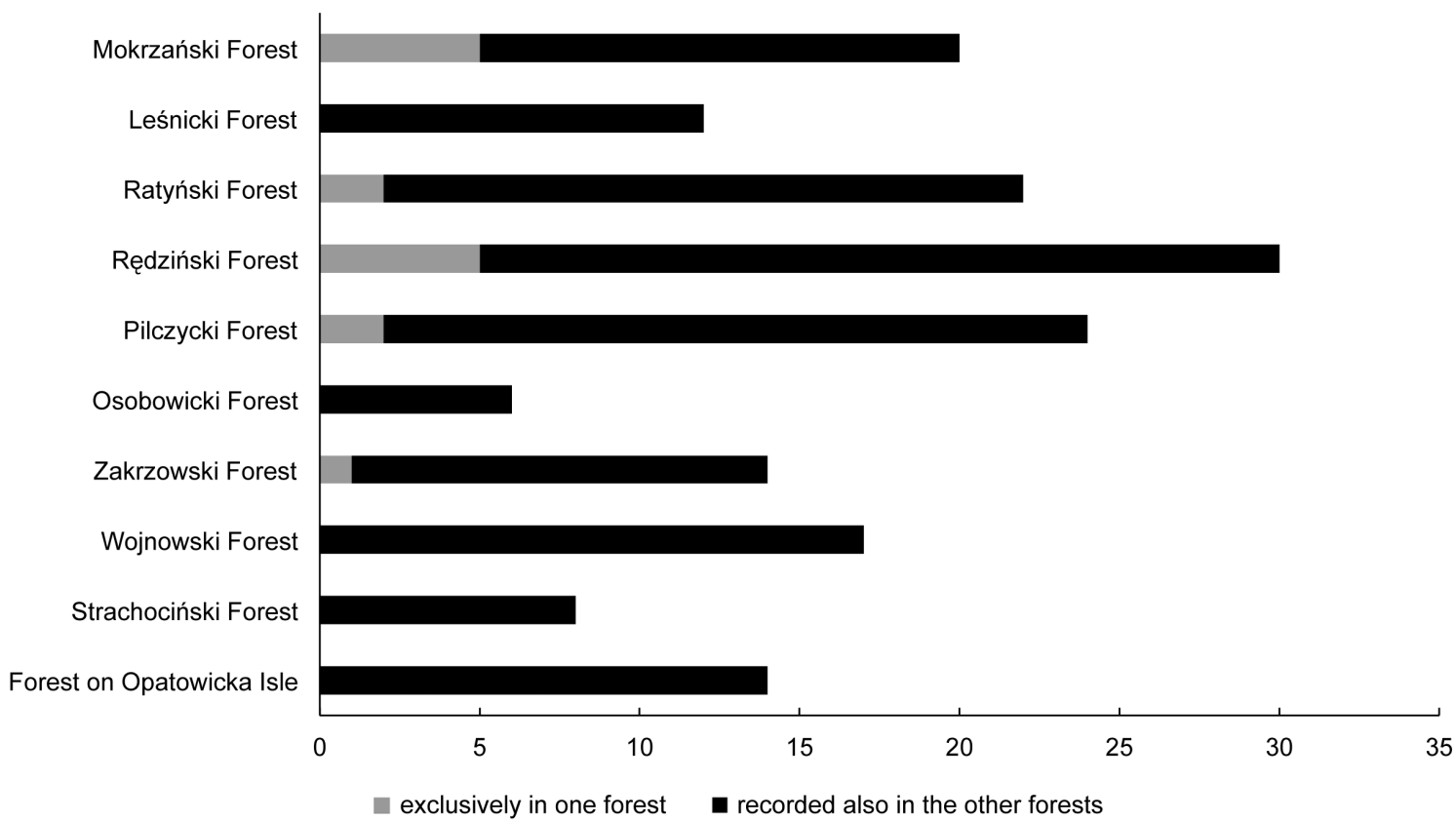

Fig. 3. Number of bryophyte species found in the individual urban forests of Wrocław, including the number of species recorded only in a given forest 


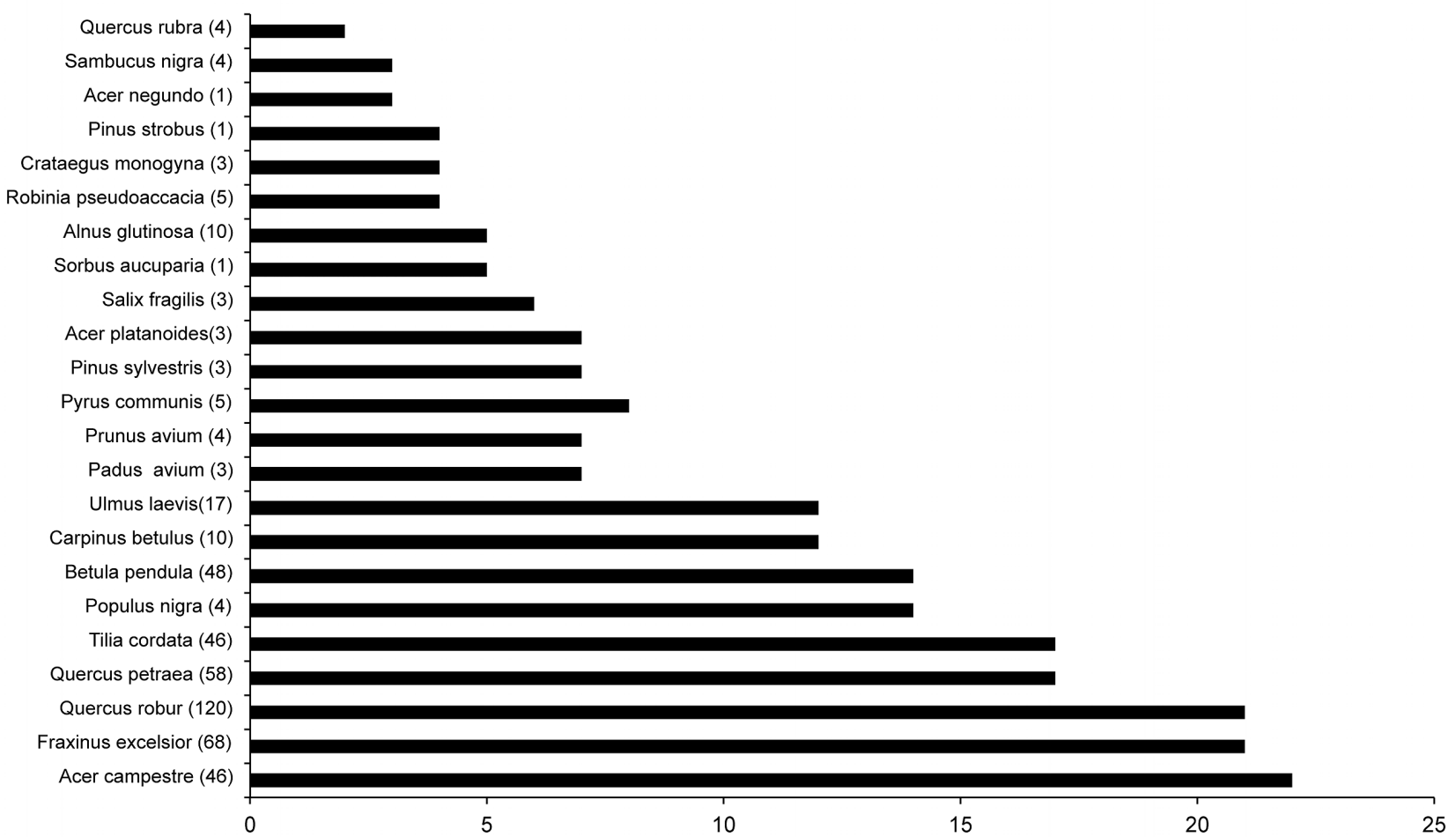

Fig. 4. Number of bryophyte species recorded on the trunks of individual host tree species in the Wrocław forests. Numbers in brackets refer to the number of tree individuals colonized by bryophytes

them in the class of 'very rare' species. Twenty seven of the latter were found on a very small number of tree individuals (no more than 23 , i.e., $5 \%$ of all colonized trunks), including eight species noted on only one tree (Table 1), which classifies them as 'extremely rare'. The group containing the most rarely recorded species was differentiated ecologically and contained both obligatory and facultative epiphytes.
Very similar relations were observed regarding the number of research squares in which the bryophyte species were recorded: Hypnum cupressiforme was noted in $82 \%$ of the plots, Platygyrium repens - in $62 \%$, Dicranoweisia cirrata - in 60\%, and Amblystegium serpens - in $42 \%$. Other species were noted in no more than 16 squares (36\%), including 25 species found in no more than 5 squares (10\%) (Table 1).

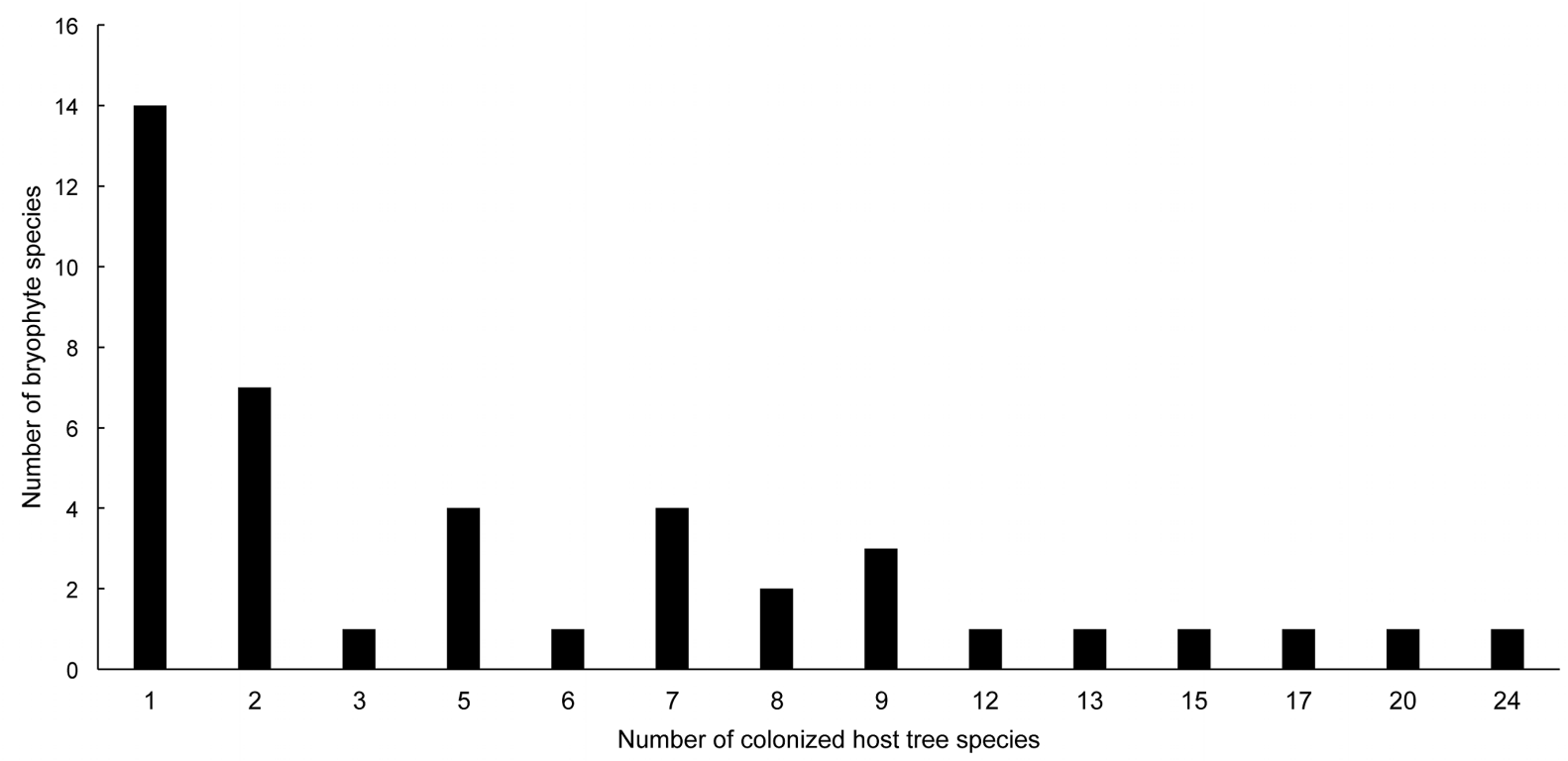

Fig. 5. Number of epiphytic bryophyte species per the number of host tree species colonized 
Table 2. Percentage incidence of individual species on the most frequently colonized host-tree species (only these bryophyte species exhibiting a clear association with tree bark as substratum); the species that were recorded on only one tree species were excluded

\begin{tabular}{|c|c|c|c|c|c|c|c|c|c|c|}
\hline Name of epiphytic species & 1 & 2 & 3 & 4 & 5 & 6 & 7 & 8 & 9 & 10 \\
\hline & \multicolumn{10}{|c|}{$\%$} \\
\hline Anomodon attenuatus & 22 & . & 5 & . & 63 & . & 5 & . & 5 & 0 \\
\hline Dicranoweisia cirrata & 1 & 2 & 28 & 2 & 2 & 16 & 27 & 14 & 1 & 7 \\
\hline Dicranum scoparium & . & . & 46 & . & . & 19 & 19 & 4 & . & 12 \\
\hline Homalia trichomanoides & 23 & . & . & . & 67 & 3 & 3 & . & . & 4 \\
\hline Hypnum pallescens & 6 & . & 6 & 6 & 6 & 28 & 28 & 9 & . & 11 \\
\hline Leskea polycarpa & 17 & . & . & . & . & 50 & . & . & . & 33 \\
\hline Orthodicranum montanum & . & . & 13 & 4 & 4 & 17 & 43 & 13 & . & 6 \\
\hline Orthodicranum tauricum & . & . & 33 & . & . & 8 & 25 & 25 & . & 8 \\
\hline Orthotrichum affine & 7 & . & . & 4 & 15 & 4 & 41 & . & 4 & 25 \\
\hline Orthotrichum pumilum & 12 & 4 & 4 & 4 & 19 & 15 & 19 & 4 & 8 & 11 \\
\hline Plagiothecium laetum & . & . & 33 & . & . & . & . & 67 & . & 0 \\
\hline Platygyrium repens & 4 & 3 & 5 & 2 & 20 & 10 & 35 & 14 & 3 & 4 \\
\hline Radula complanata & 10 & . & . & . & 52 & . & 14 & 5 & 10 & 9 \\
\hline Amblystegium serpens & 34 & . & . & 1 & 30 & 1 & 2 & 3 & 9 & 20 \\
\hline Hypnum cupressiforme & 8 & 2 & 8 & 2 & 12 & 14 & 34 & 10 & 2 & 8 \\
\hline Lophocolea heterophylla & 3 & . & 38 & . & 9 & 6 & 31 & 6 & . & 7 \\
\hline Orthotrichum diaphanum & 22 & . & . & 11 & 33 & . & 11 & 11 & . & 12 \\
\hline Rosulabryum moravicum & 55 & . & . & 3 & 23 & 3 & . & 3 & 8 & 5 \\
\hline Sciuro-hypnum populeum & 30 & . & . & . & 70 & . & . & . & . & 0 \\
\hline
\end{tabular}

Explanations: 1 -Acer campestre, 2 - Alnus glutinosa, 3 -Betula pendula, 4 -Carpinus betulus, 5 -Fraxinus excelsior, 6 -Quercus petraea, 7 -Quercus robur, 8 - Tilia cordata, 9 - Ulmus laevis, 10 - other tree species together

Analysis of the species distribution in individual forests showed that four moss species, Dicranoweisia cirrata, Hypnum cupressiforme, Platygyrium repens and Orthotrichum pumilum, were noted in all of them (10), and one (Ortotrichum affine) in almost all (9) (Table 1). 16 species were recorded in only one forest, but only four of them were classified as obligatory epiphytes: Anomodon viticulosus, Isothecium alopecuroides, Metzgeria furcata and Ptilidium pulcherrimum (Fig. 3, Table 1).

The two most frequent species occupied $51 \%$ of the total area covered with bryophytes in the reléves: Hypnum cupressiforme - 46\%, and Platygyrium repens $-5 \%$ (Table 1 ). With regard to other species, the total surface covered in the reléves was very small, with the exception of two species classified as 'rare': Dicranoweisia cirrata (the species cover was 7\%) and Amblystegium serpens (10\%). Bryophytes were not evenly distributed around the trunks, most of them (76\%) occurred within a sector surrounding the trunks from west to north $\left(270-360^{\circ}\right)$.

\subsection{Relation to the host tree species}

The trunks of 24 tree species were colonized by bryophytes, including 14 tree species with the number of colonized individuals less than 10 (Fig. 4). The highest species richness of epiphytic species was recorded for five host tree species: Acer campestre L., Fraxinus excelsior L., Quercus robur, Q. petraea and Tilia cordata Mill. (Fig. 4).

The number of host tree species colonized by a given epiphyte species varied between 1 and 24 (Fig. 5 ), but most of bryophytes colonized the trunks of no more than six phorophytes. 14 bryophyte species were recorded on trunks of only one host tree species. Seven of these species were classified as obligatory epiphytic bryophyte (Table 1).

In spite of their ability to colonize the trunks of many tree species, most epiphytes showed a preference to grow more frequently only on some of them (Table 2). Among the species that prefer the trunks of Quercus robur were: Dicranoweisia cirrata, Hypnum cupressiforme, H. pallescens, Lophocolea heterophylla, Orthotrichum affine and Orhodicranum montanum. The taxa preferring Betula pendula included: Dicranoweisia cirrata, Lophocolea heterophylla, Dicranum scoparium, and Orthodicranum tauricum, while on Fraxinus excelsior occurred: Anomodon attenuatus, Homalia trichomanoides, Radula complanata, Sciuro-hypnum populeum, Amblystegium serpens and Orthotrichum diaphanum. Finally, Rosulabryum moravicum and Amblystegium serpens preferred trunks of Acer campestre, while Hypnum pallescens and Leskea polycarpa - of Quercus petraea. 


\section{Discussion}

Faced with the scarcity of bryological records from wooded areas in the Odra valley, both historical and contemporary, it is difficult to make a precise estimation of the bryo-epiphytic flora and its dynamics with respect to species richness in the Wroclaw urban forests. The urban forests of Wroclaw are generally fairly strongly affected by the anthropogenic changes and, therefore, far from their previous natural form. However, when compared to the forest reserves in Central Poland of quite similar forest stand structure (Fudali \& Wolski 2015), they are only slightly less rich in epiphytic bryophyte species. On the other hand, the number of obligatory epiphytic bryophytes (17) found in the urban forests of Wroclaw is much lower than that reported from the forests of Brussels (25 - Vanderpoorten 1997), Bratislava (22 - Janovicovà et al. 1998), and Katowice (22 - Fojcik \& Stebel 2014). However, the data quoted are not fully comparable because of differences in the research methods (systematic searching vs. sampling based on the randomly established study square network in this survey), the way the data were presented and the size of the studied area. In respect to floristic similarity, the epiphytic bryoflora of Wroclaw forests is in 50-60\% the same as in the cities listed above. However, it should be emphasized that afforested area in Wrocław (7.6\%) is much smaller as compared with mentioned cities.

Compared to forest reserves in Central Poland (Fudali \& Wolski 2015), the number of host tree species colonized by particular epiphytic species in the Wroclaw forests was higher, which may result from the differences in the structure of forest stands (in Central Poland, these stands are strongly distorted due to pine plantations, and enriched with the natural occurrence of fir, Abies alba). Another factor could be that the forests of Wroclaw are located in river valleys, thus, proximity to water favours the development of epiphytes (Richter et al. 2009; Pentecost 2014). According to Frahm (1992), host tree specificity is really pronounced only in dry regions. However, in the forests of Wroclaw, some epiphytes showed noticeable preferences to colonize more frequently only a few of the host tree species; mostly Fraxinus excelsior, Quercus robur, Q. petraea and Acer campestre. The two first were pointed by Barkmann (1958) as tree species harbouring the most rich epiphytic bryoflora in Europe. The importance of ash tree for epiphytic bryophytes as a preferred phorophyte for many species in southern Britain was emphasized by Bates et al. (1997) and Pentecost (2014). Bates et al. (1997) found also that Acer campestre, not as frequently colonized as ash tree, supported many rare epiphytic species. In our study, both tree species hosted a very similar number of epiphytic bryophytes, but ash tree had more rare species.
Seventy four per cent of the epiphytes recorded in the Wroclaw forests also occurred in the city parks (Fudali 2001,2012) and only seven species seem to be restricted to forests: two liverworts, Metzgeria furcata and Radula complanata, and five mosses, Anomodon attenuatus, A. viticulosus, Sciuro-hypnum reflexum, Homalia trichomanoides, and Isothecium alopecuroides. Ecologically, they are sciophytes (3 taxa) or species able to live in moderately lit sites (4). They prefer moderately humid to moderately dry microhabitats (Dierssen 2001), which explains their attachment to the forest habitats. Three of the species, Anomodon viticulosus, A. attenuatus and Homalia trichomanoides, are considered to be primeval forest relics (Stebel \& Żarnowiec 2014). The two latter were estimated as common around Wroclaw in the 19th century (Milde 1869) but in the second half of the 20th century, the species were not found frequently in this area (Górski et al. 2017; and literature quoted therein). Their recorded sites were concentrated in three forests situated in western and northern part of the city along the Odra river and Bystrzyca river valleys and a phorophyte preferred was Fraxinus excelsior. Our study showed that populations of these epiphytes have been preserved in the area studied. Anomodon viticulosus has not been reported from the Wroclaw environs so far (Fudali 1998) and during this study, the species was found only once.

In other cities, the percentage incidence of epiphytes noted in forests, which were also found in built-up areas, was lower: Szczecin had 72\% (Fudali 1997), Brussels 44\% (Vanderpoorten 1997), and Bratislava 40\% (Janovicovà et al. 1998).

Among the species recorded in the Wroclaw urban forests, there are some that have been reported as expansive in recent decades (Greven 1996; Söderström 1992; Stebel et al. 2015). One of them, Platygyrium repens, which is quite frequent and widely distributed nowadays in the Wroclaw urban forests was reported by Milde (1869) only from the Las Osobowicki forest, where it is still present. The species was also found in the Wroclaw parks but in a small number of localities (Fudali 2012). According to Dierssen (2001), Platygyrium repens requires humid air and this may be a factor controlling its expansion in urbanised areas. The second species, Orthodicranum montanum, was reported by Milde (1869) from the Wroclaw vicinity without estimation of its frequency. At present, this species occurs very rarely in the forests of Wroclaw and it is extremely rare in the parks. The same pattern of $O$. montanum occurrence was found in Szczecin (Fudali 1997), whereas in Brussels (Vanderpoorten 1997), Bratislava (Janovicovà et al. 1998) and Katowice (Fojcik \& Stebel 2014), it was recorded only in forests. Vanderpoorten et al. (2004) consider this species as an indicator of old forests in Belgium. These data are in disagreement with the Dierssen's (2001) opinion that 
O. montanum has been 'increasing in urban areas in recent years'.

The first records of Orthodicranum tauricum and Hypnum pallescens in Wroclaw are dated 2011 and refer to three and six trunks, respectively (Fudali 2012). In the urban forests, O. tauricum was found on 13 trees. According to Stebel et al. (2012), the majority of individuals of this species in Central-East Europe that have been documented so far occured in forests. It tolerates moderately dry and light habitats (Dierssen 2001), thus, it might find potentially favourable conditions in managed forests and in large city parks. It also appears to be highly effective at propagation through broken leaf apices. The number of trees colonised by H. pallescens in the Wrockaw urban forests was 38 . This species is considered to be a moderate sciophyte that prefers sites that are not extremely dry (Dierssen 2001) and this factor can limit its ability to spread out of the forests. Both discussed species were observed mainly in the forests of the western and northwestern edges of Wroclaw and only in those large city parks that are similarly situated, which corresponds with the most frequent wind directions. This suggests an early phase of settlement of these species in the region.

Orthotrichum pumilum was reported as frequent around Wroclaw in the past (Milde 1869) and at the present time, it was recorded on the trunks of 40 trees in all forests studied, but before 2011, it was not recorded in the city (Fudali 2012) and then (in 2011), it was found on only one trunk. However, nowadays, it is observed quite frequently on tree trunks in built-up areas of Wroclaw (Fudali 2018). In the last decades, this thermophytic, xerophytic and photophytic epiphyte has changed its occurrence frequency also in the city of Katowice (Stebel \& Fojcik 2016). According to Vanderpoorten et al. (2004), Orthotrichum pumilum appears to occur more frequently in open woodlands and thickets than in forests.

In reference to fragmentary historical data (see: Introduction), six species were not rediscovered during this study: Anomodon longifolius, Ortotrichum fastigiatum, O. Lyellii, O. stramineum, O. tenellum and Amblystegium juratzkanum.

\section{Conclusions}

In respect of species composition and relative frequency of taxa, the flora of epiphytic bryophytes occurring in the urban forests of Wroclaw still seems to be forest-like in character; the incidence of non-forest species is negligible, both in relation to the number of species (14\% of bryoflora) and their abundance records. The maintenance of primeval forest relic-species: Homalia trichomanoides, Anomodon attenuates and A. viticulosus, gives this flora an additional natural value. Unfortunately, most of the species connected with forests occurred on a very small number of tree trunks and in extremely small populations. This feature makes the epiphytic bryoflora taxonomically monotonous and poor on the spatial scale: the dominance of two species - Hypnum cupressiforme and Platygyrium repens, is spectacular.

In general terms, the flora of epiphytic bryophytes in the Wroclaw urban forests shows a high floristic similarity to the epiphytic bryoflora recorded in the city parks. However, the groups of forest species that only sporadically occurred in the parks combined with those that were recorded only in the forests comprise $63 \%$ of the total forest epiphytes. Thus, for the preservation of the epiphytic bryophyte diversity in Wroclaw, the conservation of forest habitats is required, especially, taking special care of forest stands composed of ashtrees, oaks and field maples as these are the trees most frequently colonized by epiphytic bryophytes and hosting the highest number of obligatory epiphytes. Monitoring of epiphytic species of high natural value is also required and the data provided in this study could be a background for future observations.

Acknowledgments. We thank Aleksander Dembiński for help in determining the current names and positions of old German localities of the bryophyte species.

\section{Author Contributions}

Research concept and design: E. Fudali, L. Żołnierz Acquisition and/or assembly of data: E. Fudali, L. Żołnierz Data analysis and interpretation: E. Fudali, L. Żołnierz Drafting the article: E. Fudali, L. Żołnierz Critical revision: E. Fudali, L. Żołnierz Final approval: E. Fudali, L. Żołnierz 


\section{References}

Alvey A. A. 2006. Promoting and preserving biodiversity in the urban forest. Urban forestry and Urban Greening 5: 195-201. doi: 10.1016/j.ufug.2006.09.003

Barkman J. J. 1958. Phytosociology and ecology of cryptogamic epiphytes. I-XIII + 628 pp. Van Gorcum \& Comp. N.V., Assen.

Bates W., Proctor M. C. F., Preston C. D., Hodgetts N. G. \& Perry A. R. 1997. Occurrence of epiphytic bryophytes in a 'tetrad' transect across southern Britain. 1. Geographical trends in abundance and evidence of recent change. J Bryol 19: 685-714.

BERDOwSKI W. 1974. Flora mchów i zbiorowiska mszaków masywu Ślęży. Monogr Bot 45: 1-125.

Cichocki Z. (ed.). 2006. Środowisko Wrocławia - informator 2006. 212 pp. Agencja Wydawnicza “Argi”, Wrocław.

DEARBorn D.C. \& Kark S. 2009. Motivations for conserving urban biodiversity. Conserv Biol 24(2): 432-440. doi: 10.1111/j.1523-1739.2009.01328

Dierssen K. 2001. Distribution, ecological amplitude and phytosociological characterization of European bryophytes. Bryophytorum Bibl. 56: 1-289.

Dubicki A., Dubicka M. \& Szymanowski M. 2002. Wroclaw climate. Directory of Wroclaw Environment, pp. 9-25. Lower Silesian Foundation for Suitable Development, Wrocław.

Dyderski M. K., Wrońska-Pilarek D. \& Jagodziński A.M. 2017. Ecological lands for conservation of vascular plant diversity in the urban environment. Urban Ecosyst. 20: 639-650. doi: 10.1007/s11252-016-0625-2

Fojcik B. \& Stebel A. 2014. The diversity of moss flora of Katowice town (S Poland). Cryptogamie, Bryol. 35(4): 373-385. doi/10.7872/cryb.v35.iss4.2014.373

FRAHM J. P. 1992. Untersuchungen zur epiphytischen Moosvegetation der Vogesen. Herzogia 9: 213-228.

FUDALI E. 1996. Distribution of bryophytes in various urbanuse complexes of Szczecin. Fragm Flor Geobot 41(2): 717-745.

Fudali E. 1997. Brioflora Szczecina. II. Mszaki lasów miejskich. Fragm Flor Geobot Polonica 4: 75-88.

FudALI E. 1998. Investigations of bryophytes in Polish towns - a rewiev of the bryological research and data. Fragm Flor Geobot 43(1): 77-101.

FudALi E. 2001. The ecological structure of the bryoflora of Wrocław's parks and cemeteries in relation to their localization and origin. Acta Soc Bot Pol, 70(3): 229-235.

FudALI E. 2011. Zmiany zachodzące współcześnie w brioflorze miast - na przykładzie parków Wrocławia (obserwacje $z$ lat 2000, 2006, 2011). Acta Bot Siles 6: 63-77.

FUDALI E. 2012. Recent tendencies in distribution of epiphytic bryophytes in urban areas: a Wrocław case study (south-west Poland). Polish Bot J 57(1): 231-241.

FudALI E. 2018. Ekspansja epifitycznego mchu Orthotrichum pumilum Sw. na terenie Wrocławia. Fragm Flor Geobot Polonica 25(2): 295-298.

Fudali E. \& WolsKi G. J. 2015. Ecological diversity of bryophytes on tree trunks in protected forests (a case study from Central Poland). Herzogia 28(1): 91-107.
Górski P., Fudali E., ŻoŁnierz L., Smoczyk M., Wierzcholska S., Rosadziński S. \& Dyderski M. K. 2017. New distributional data on bryophytes of Poland and Slovakia, 10. Steciana 21(2): 59-68. doi: 10.12657/ steciana.021.007

Greven H. C. 1992. Changes in the Dutch bryophyte flora and air pollution. Diss Bot 194: 3 -180.

JACKOWIAK B. 1998. Struktura przestrzenna flory dużego miasta. Studium metodyczno-problemowe. Prace Zakładu Taksonomii Roślin UAM 8, pp. 227. Bogucki Wyd. Nauk., Poznań.

JANOvicovà K., Kubinskà A. \& JaVorČIKovÀ D. 2003. Liverworts (Hepatophyta), Hornworts (Anthocerotophyta) and Mosses (Bryophyta) in the area of Bratislava (Slovakia), pp. 38-92. Botanický Ústav of Slovac Academy of Sciences, Bratislava.

KowARIK I. 1990. Some responses of flora and vegetation to urbanization in Central Europe. In: H. Sukopp (ed.). Urban Ecology, pp. 45-74. SPB Academic Publishing bv., The Hague.

Lewicki Z. (ed.). 2014. Środowisko Wrocławia. 131 pp. Wydawnictwo Lemitor Ochrona Środowiska sp. z o.o., Wrocław.

Matuszkiewicz W., Faliński J. B., Kostrowicki A. S., Matuszkiewicz J. M., Olaczek R. \& Wojterski T. 1995. Potencjalna roślinność naturalna Polski. Mapa przeglądowa 1:300 000. Instytut Geografii i Przestrzennego Zagospodarowania, Polska Akademia Nauk, Warszawa.

McKinney M. L. 2006. Urbanization as a major cause of biotic homogenization. Biol Conserv 127: 247-260. doi: 10.1016/j.biocon.2005.09.005

MeŽaka A., Brümelis G. \& Piterāns A. 2008. The distribution of epiphytic bryophyte and lichen species in relation to phorophyte characters in Latvian natural old-growth broad leaved forests. Folia Cryptog. Estonica 44: 89-99.

Milde J. 1869. Bryologia Silesiaca, Laubmoos-Flora von Nord- und Mittel-Deutschland, unter besonderer Berücksichtigung Schlesiens und mit Hinzunahme der Floren von Jütland, Holland, der Rheinpfalz, von Baden, Franken, Böhmen, Mähren und der Umgegend von München. ix +410 pp. Verlag von Arthur Felix, Leipzig.

Mirek Z., PięKoś-Mirkowa H., Zając A. \& Zając M. 2002. Flowering plants and pteridophytes of Poland. A checklist. In: Z. MireK (ed.). Biodiversity of Poland, 1, 442 pp. W. Szafer Institute of Botany, Polish Academy of Sciences, Kraków.

Ochyra R., Żarnowiec J. \& Bednarek-Ochyra H. 2003. Census Catalogue of Polish Mosses. In: Z. Mirek (ed.). Biodiversity of Poland, 3, 372 pp. Polish Academy of Sciences, Institute of Botany, Kraków.

Pentecost A. 2014. The cryptogamic epiphytes of ash (Fraxinus excelsior L.) in an ancient pasture-woodland: relationships with some environmental variables of relevance to woodland epiphyte management. Cryptogamie, Bryol. 35(1): 19-36. doi/10.7872/cryb. v35.iss 1.2014.19 
Richter S., Schütze P. \& Bruelheide H. 2009. Modelling epiphytic bryophyte vegetation in an urban landscape. J Bryol 31: 159-168. doi: 10.1179/174328209x431277

SEward M. R. D. 1979. Lower plants and the urban landscape. Urban ecology 4: 217-225.

Sérgio C., Carvalho P., Garcia C. A., Almeida E., Novais V., Sim-Sim M., Jordão H. \& SousA A. J. 2016. Floristic changes of epiphytic flora in the Metropolitan Lisbon area between 1980-1981 and 2010-2011 related to urban air quality. Ecological Indicators 67: 839-852. dx/doi.org/10.1016/jecolind.2016.03.022

SöDERSTRÖM L. 1992. Invasions and range expansions and contractions of bryophytes. In: J. W. BATES \& A. M. FARMER (eds.). Bryophytes and lichens in a changing environment, pp. 131-157. Oxford University Press, Oxford.

Stapper N. J. \& Kricke R. 2004. Epiphytische Moose und Flechten als Bioindikatoren von städtischer Überwärmung, Standorteutrophierung und verkehrsbedingten Immissionen. Limprichtia 24: 187-208.

Stebel A. \& Fojcik B. 2016. Changes in the epiphytic bryophyte flora in Katowice city (Poland). Cryptogamie, Bryol. 37(4): 399-414. doi/10.7872/cryb.v37.iss4.2016.399
Stebel A., Virchenko V. M., Plášek V., Ochyra R. \& Bednarek-Ochyra H. 2012. Range extension of Orthotrichum tauricum (Bryophyta, Dicranaceae) in Central-East Europe. Polish Bot J 57(1): 119-128.

Stebel A. \& Żarnowiec J. 2014. Gatunki puszczańskie we florze mchów Bieszczadzkiego Parku Narodowego (Karpaty Wschodnie). Roczniki Bieszczadzkie 22: 259-277.

SzWEYKOWSKi J. 2006. An annotated checklist of Polish Liverworts and Hornworts. 114 pp. W. Szafer Institute of Botany, Polish Academy of Sciences, Kraków.

VANDERPOORTEN A. 1997. A bryological survey of the Brussels Capital Region (Belgium). Scripta Botanica Belgica 14: 3-39.

Vanderpoorten A., Engels P. \& Sotiaux A. 2004. Trends in diversity and abundance of obligate epiphytic bryophytes in a highly managed landscape. Ecography 27: 576-576.

WINNER W. E. 1988. Responses of bryophytes to air pollution. In: J. Cramer (ed.) Lichens, Bryophytes and Air Quality. Bibl. Lichenol. 30: 141-173, Berlin-Stuttgart. 